\title{
Linking Engineered Cells to Their Digital Twins: A Version Control System for Strain Engineering
}

Jonathan Tellechea-Luzardo ${ }^{1+}$, Charles Winterhalter ${ }^{1+}$, Paweł Widera ${ }^{1}$, Jerzy Kozyra $^{1}$, Víctor de Lorenzo $^{2}$, Natalio Krasnogor ${ }^{1 *}$

${ }^{1}$ Interdisciplinary Computing and Complex Biosystems (ICOS) research group, Newcastle University, Newcastle Upon Tyne, UK

${ }^{2}$ Systems and Synthetic Biology Program, Centro Nacional de Biotecnología (CNB-CSIC), 28049 Madrid, Spain.

+ Joint first authors

*Correspondence to: Natalio.Krasnogor@newcastle.ac.uk

\section{Supplementary Material}

\section{BARCODE DESIGN}

The encoding method behind our DNA barcodes relies on universally unique identifiers (UUIDs). Initially used by Microsoft to create encoded object identifiers, we used the UUID version 4 algorithm to generate random 32-hexadecimal character sequences. Because these are randomly generated, there are about $5.3 \times 10^{36}$ different possibilities of UUIDs of this type. Therefore, UUIDs allowed us to set a potentially largescale system for the barcoding of bacterial species.

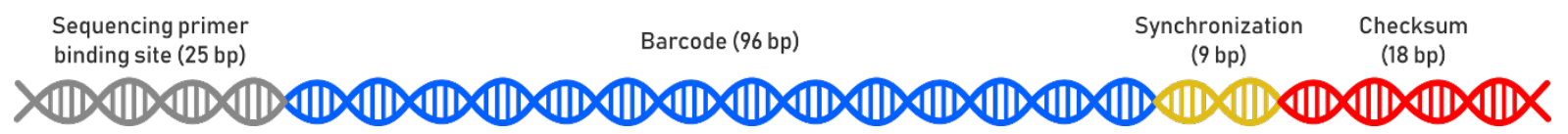

Figure S1: DNA barcodes genetic structure. DNA barcodes can be read through targeted sequencing at a universal primer binding site. Their structure is divided in subsequences that correspond to a specific UUID (96bp), a recognition synchronization sequence $(9 b p)$ and a checksum for UUID read inaccuracies (18bp).

Based on the redundancy of the genetic code, we encoded each UUID hexadecimal character as a chain of three nucleotides, which resulted in constructing 96bp DNA barcodes (Figure S1). To account for variability in sequencing results, we also integrated an error-correction mechanism to account for truncated or partially incorrect reads. This was done via a $9 \mathrm{bp}$ recognition sequence that our decoding algorithm searches for, in order to align sequencing reads of variable lengths. Once this sequence is found, its upstream region maps a UUID reference encoded as 96 nucleotides, while downstream 18 bases correspond to the checksum for errors handling. Barcodes generated with our platform are kept in a secure database and mapped to sequencing reads in order to retrieve barcoded strain profile content. Should there be any misalignment between a sequencing read and a UUID, the checksum is used as a secondary encoding method to provide better chance of retrieving strain documentation in poor sequencing conditions.

\section{Bioorthogonality}

In the design process of DNA barcodes, we reduced the possibility of biological interaction between the synthetic barcoding DNA and cellular machinery. While our encoding method created random DNA barcodes, most sequences would still display biological features to some extent. As a standard tool for cloning, restriction enzymes are molecular subunits that generally recognize sequences of 4 to 8 nucleotides and cleave these sequences, which were removed from our barcodes. During barcode generation, we removed over 180 recognition sequences from barcodes, which covered a vast majority of known restriction sites. Figure S2 shows a conflicting case of DNA sequence containing a restriction enzyme site, and how it could be removed by using redundancy of the DNA encoding method. For each UUID hexadecimal character, there were 4 possibilities of nucleotide triplets (Figure S2 A). Therefore, our algorithm allowed use of an alternative triplet in conflicting cases, where a sequence had to be changed to 
alleviate any potential biological interaction. In a similar fashion, and for sequencing needs this time, we limited the appearance of single- or di-nucleotide repetitions in barcode sequences. These tend to decrease the quality of sequencing reads, especially in Sanger sequencing. Besides practical consideration for sequence retrieval, removing repetitive features also minimized the chances of mutations appearing due to DNA polymerases sliding over long DNA stretches of the same nucleotide. Then, we removed sequences that would locate a protein start codon in the proximity of potential ribosome binding sites via a transcriptional/translational unit screen. Finally, we performed a BLAST alignment against the target genome for each species to ensure that the barcode sequence had little to no similarity with it.

A
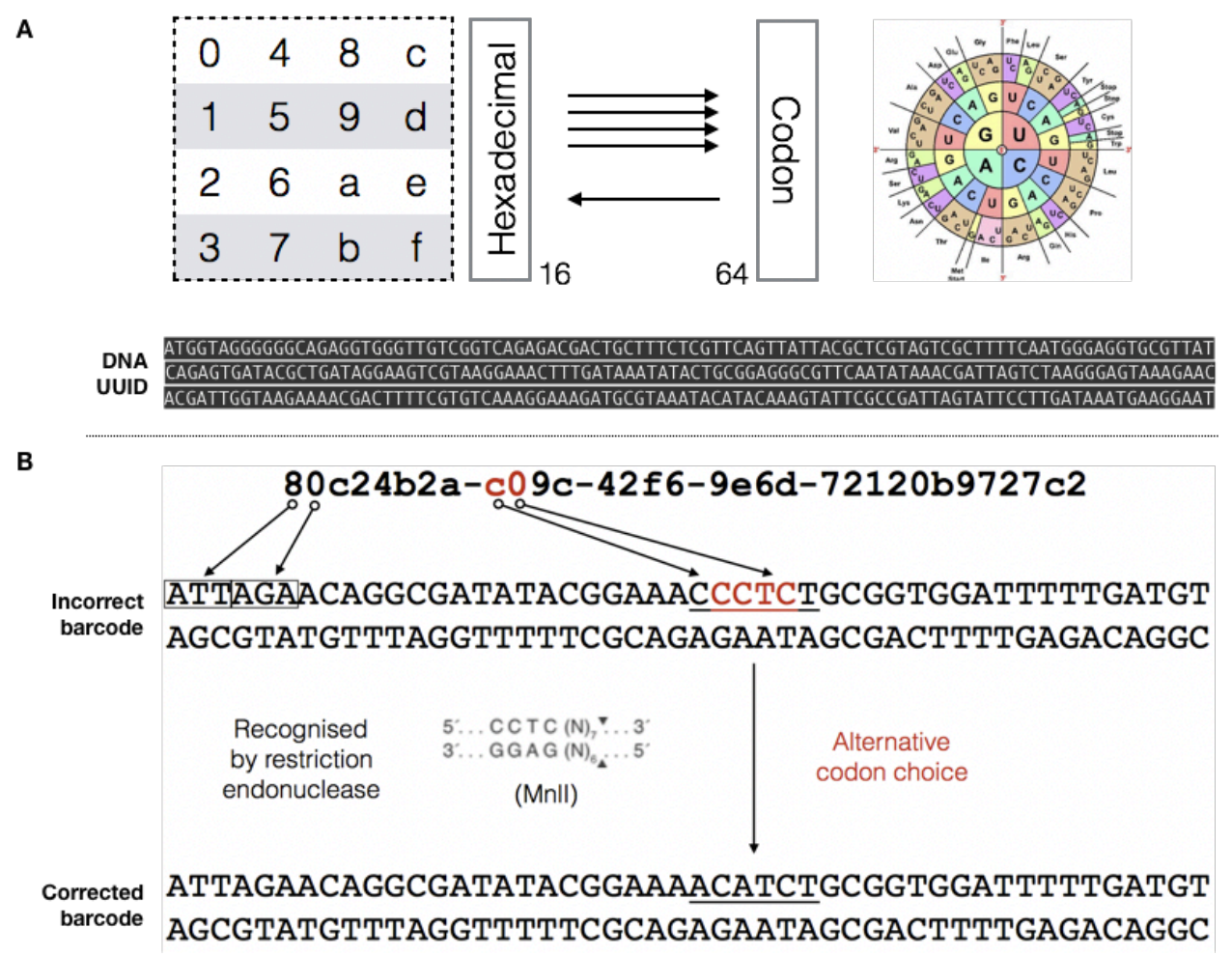

Figure S2: DNA barcode redundancy. (A) Each UUID hexadecimal character corresponds to four possible DNA nucleotide triplets (or codons), while each codon can only match one hexadecimal character. When UUID hexadecimal characters are converted to nucleotide triplets, undesirable sequences (for example, the Mnll enzyme restriction site in $(B)$ ) are directly removed by choosing one of three alternative triplet possibilities that would comply with all the barcode design concepts.

The algorithm is in its early stages and we plan to keep improving and producing better versions with more certainty that the barcodes are as "biorthogonal" as possible. In future research we would like to include complementary biorthogonality criteria such as those reported in ${ }^{1}$.

\section{E. COLI BARCODING PROTOCOLS}

Lambda-red recombineering. Adapted from ${ }^{2}$

Day 1:

1. Start an overnight culture $\left(37^{\circ} \mathrm{C}\right)$ by inoculating $L B$ medium from a single colony.

Day 2:

1. Prepare competent cells following your favorite protocol.

2. Transform E. coli cells with plasmid pKD46 and plate the cells at $30^{\circ} \mathrm{C}$ in LB/Amp (or Carbenicillin) 
Day 3:

1. Start an overnight culture at $30^{\circ} \mathrm{C}$ in LB/Amp from a single colony.

Day 4:

1. Next morning refresh the culture with LB/Amp and grow the cells until OD600 reaches 0.1 .

2. Add arabinose to a final concentration of $30 \mathrm{mM}$ and grow the cells to an OD600 $=0.5$ (recombination proteins are being expressed at this point).

3. Frost cells on ice for 20 minutes and prepare electrocompetent cells by washing bacteria with ice-cold milli-Q water after spinning aliquots $10 \mathrm{~min}$ at $5000 \mathrm{rpm}$ in a $4^{\circ} \mathrm{C}$ centrifuge.

4. After 2 washes, resuspend cells in the residual water and electroporate with $500 \mathrm{ng}$ barcode DNA cassette (coming from the amplification of $\mathrm{pEC}-\mathrm{BC}$ ) with a Gene Pulser $(25 \mu \mathrm{F}, 200 \mathrm{ohms}$ at $1.8 \mathrm{kV})$.

5. After electroporating the cells, add $950 \mu$ of fresh LB without antibiotics to samples and resuspended cultures are grown for $2 \mathrm{~h}$ at $37^{\circ} \mathrm{C}$.

6. Plate cells in LB/Cam.

Day 5:

1. Restreak colonies on LB/Cam and grow overnight at $37^{\circ} \mathrm{C}$.

Day 6:

1. Perform PCR and sequencing experiments to check the proper insertion has occurred.

2. To remove the antibiotic cassette, the pCP20 plasmid is transformed. Prepare liquid culture of cells containing the barcoding cassette in LB/Cam.

Day 7:

1. Prepare competent cells and transform pCP20 at $30^{\circ} \mathrm{C}$.

2. Plate in LB/Cam/Amp

Day 8:

1. After $p C P 20$ transformation, inoculate single colonies in LB/Amp/Cam and grow overnight at $30^{\circ} \mathrm{C}$.

Day 9:

1. Next morning, dilute cells in LB and grow at $30^{\circ} \mathrm{C}$ until OD600 reaches 0.1

2. Swap cells to $42^{\circ} \mathrm{C}$ incubator and grow until OD600 reaches 0.9 .

3. Spot $30 \mu \mathrm{L}$ in LB plate, streak over the plate and incubated at $37^{\circ} \mathrm{C}$.

Day 10:

1. Barcode presence is checked again by PCR and sequencing. 
2. Restreak single colonies in three different plates (LB, Cam and Amp) to check resistances loss.

CRISPR. Adapted from ${ }^{3}$

(Note) sgRNA sequence used: 5' - promoter - CAGCACGATGAATCTGTTAG - scaffold - terminator 3'. sgRNA sequence obtained using ${ }^{4}$.

Day 1:

1. Start an overnight culture $\left(37^{\circ} \mathrm{C}\right)$ by inoculating $L B$ medium from a single colony.

Day 2:

1. Prepare competent cells following your favorite protocol.

2. Transform E. coli cells with plasmid pREDCas 9 and plate the cells at $30^{\circ} \mathrm{C}$ in LB/Spec.

Day 3:

1. Start an overnight culture at $30^{\circ} \mathrm{C}$ in LB/Spec from a single colony.

Day 4:

1. Next morning refresh the culture with LB/Spec and grow the cells until OD600 reaches 0.1 .

2. Add IPTG to a final concentration of $2 \mathrm{mM}$ and grow the cells to an OD600 $=0.6$ (recombination proteins are being expressed at this point).

3. Frost cells on ice for 20 minutes and electrocompetent cells are then prepared by washing bacteria with ice-cold milliQ water after spinning aliquots $10 \mathrm{~min}$ at $5000 \mathrm{rpm}$ in a $4^{\circ} \mathrm{C}$ centrifuge. (Heat shock transformation also could be performed)

4. After 2 washes, resuspend cells in the residual milliQ water and electroporated with pEC-CRISPR-BC.

5. After zapping cells, add $950 \mu$ l of fresh LB without antibiotics and resuspend cells. Incubate cells $1 \mathrm{~h}$ at $30^{\circ} \mathrm{C}$.

6. Then, spread $100 \mu \mathrm{L}$ of bacterial culture on LB plates supplemented with Spec/Amp.

Day 5:

1. Check colonies for barcode presence by colony-PCR

2. Inoculate a positive clone in $2 \mathrm{~mL}$ of $\mathrm{LB} /$ Spec/Ara $(30 \mathrm{mM})$ (sgRNA targeting pUC origin in $\mathrm{pEC}-\mathrm{CRISPR}-\mathrm{BC}$ is expressed)

3. Grow for $4-6 h$

4. Plate on LB/Spec

Day 6:

1. Check some colonies for Ampicillin resistance by restreaking them on LB/Amp 
Day 7:

1. Take a sensitive clone and restreak it on LB plates at $37^{\circ} \mathrm{C}$.

Day 8:

1. Check again by colony PCR the presence of the barcode and restreak on LB/Spec and LB/Amp plates to double check plasmid curing.

\section{B. SUBTILIS BARCODING PROTOCOLS}

mazF toxin/antitoxin. Adapted from ${ }^{5}$

Day 1:

1. Inoculate $B$. subtilis cells from a single colony overnight at $37^{\circ} \mathrm{C}$ in minimal medium (MM: $10 \mathrm{ml} \mathrm{SMM} \mathrm{basic} \mathrm{salts,} 125 \mu \mathrm{l} 40 \%(\mathrm{w} / \mathrm{v})$ glucose, $100 \mu \mathrm{l} 2 \%(\mathrm{w} / \mathrm{v})$ tryptophan, $60 \mu \mathrm{l} 1 \mathrm{M} \mathrm{Mg} 2 \mathrm{SO}^{*} 7 \mathrm{H} 2 \mathrm{O}, 10 \mu \mathrm{l} 20 \%(\mathrm{w} / \mathrm{v})$ casamino acids, $5 \mu \mathrm{l} 2.2 \mathrm{mg} / \mathrm{ml}$ ferric ammonium citrate)

Day 2:

1. In the morning, dilute cells $1: 100$ in $\mathrm{MM}$ and incubate for $3 \mathrm{~h}$ at $37^{\circ} \mathrm{C}$.

2. Dilute $1: 2$ in SM (SM: $10 \mathrm{ml}$ SMM basic salts, $125 \mu \mathrm{l} 40 \%(\mathrm{w} / \mathrm{v})$ glucose, $60 \mu \mathrm{l} 1 \mathrm{M}$ $\left.\mathrm{Mg} 2 \mathrm{SO} 4^{*} 7 \mathrm{H} 2 \mathrm{O}\right)$. Incubate $2 \mathrm{~h}$ at $37^{\circ} \mathrm{C}$.

3. Mix $400 \mu \mathrm{L}$ of cells with $1 \mu \mathrm{g}$ of barcode DNA cassette. Incubate $1 \mathrm{~h}$ at $37^{\circ} \mathrm{C}$.

4. Plate cells on NA/Zeocin plates. Incubate overnight at $37^{\circ} \mathrm{C}$.

Day 3:

1. Check integration by colony PCR.

2. Incubate overnight one positive clone at $37^{\circ} \mathrm{C}$ in $\mathrm{LB} / 0.4 \%(\mathrm{w} / \mathrm{v})$ glucose/zeocin.

Day 4:

1. Dilute the culture to $O D 600=0.1$ in fresh $L B / O .4 \%(w / v)$ glucose without antibiotics and grow to OD600 $=0.4$.

2. Add $1 \%(\mathrm{w} / \mathrm{v})$ xylose. Incubate $8 \mathrm{~h}$ at $37^{\circ} \mathrm{C}$.

Day 5:

1. Plate cells on NA supplemented with $1 \%(\mathrm{w} / \mathrm{v})$ xylose.

Day 6:

1. Restreak individual colonies on NA and NA/Zeocin and colony-PCR to test for cassette removal.

Cre-Lox. Adapted from ${ }^{6}$ 
Day 1:

1. Start an overnight culture $37^{\circ} \mathrm{C}$ in minimal medium (MM: $10 \mathrm{ml} \mathrm{SMM} \mathrm{basic} \mathrm{salts,}$ $125 \mu \mathrm{l} 40 \%(\mathrm{w} / \mathrm{v})$ glucose, $100 \mu \mathrm{l} 2 \%(\mathrm{w} / \mathrm{v})$ tryptophan, $60 \mu \mathrm{l} 1 \mathrm{M} \mathrm{Mg} 2 \mathrm{SO} 4 * 7 \mathrm{H} 2 \mathrm{O}, 10 \mu \mathrm{l}$ $20 \%(\mathrm{w} / \mathrm{v})$ casamino acids, $5 \mu \mathrm{l} 2.2 \mathrm{mg} / \mathrm{ml}$ ferric ammonium citrate).

Day 2:

1. Dilute cells $1: 10$ in $M M$ and grown for $3 \mathrm{~h}$ at $37^{\circ} \mathrm{C}$. Meanwhile, starvation medium (SM: $10 \mathrm{ml}$ SMM basic salts, $125 \mu \mathrm{l} 40 \%(\mathrm{w} / \mathrm{v})$ glucose, $60 \mu \mathrm{l} 1 \mathrm{M} \mathrm{Mg} 2 \mathrm{SO} 4^{\star} 7 \mathrm{H} 2 \mathrm{O}$ ) is prepared and prewarmed at $37^{\circ} \mathrm{C}$.

2. Dilute in 1:2 SM and make competent cells with a further $2 \mathrm{~h}$ incubation period at $37^{\circ} \mathrm{C}$.

3. $400 \mu \mathrm{l}$ cell aliquots are mixed with $1 \mu \mathrm{g}$ recombinant DNA PCR (coming from the amplification of pBS-CreLox-BC). Incubate $1 \mathrm{~h}$ at $37^{\circ} \mathrm{C}$.

4. Cells are spun down, concentrated and plated on NA/Zeocin $(20 \mu \mathrm{g} / \mathrm{mL})$ and incubated at $37^{\circ} \mathrm{C}$.

Day 3:

1. Colonies are tested for the integration of the recombinant DNA by PCR and sequencing.

2. A positive clone is grown overnight at $37^{\circ} \mathrm{C}$ in $\mathrm{MM}$.

Day 5:

1. Dilute cells $1: 10$ in $\mathrm{MM}$ and grown for $3 \mathrm{~h}$ at $37^{\circ} \mathrm{C}$. Meanwhile, starvation medium (SM: $10 \mathrm{ml} \mathrm{SMM} \mathrm{basic} \mathrm{salts,} 125 \mu \mathrm{l} 40 \%$ (w/v) glucose, $60 \mu \mathrm{l} 1 \mathrm{M} \mathrm{Mg} 2 \mathrm{SO} 4{ }^{*} 7 \mathrm{H} 2 \mathrm{O}$ ) is prepared and prewarmed at $37^{\circ} \mathrm{C}$.

2. The culture is diluted 1:2 in SMM and cells are made competent with a further $3 \mathrm{~h}$ incubation period at $37^{\circ} \mathrm{C}$.

3. $400 u l$ cell aliquots are mixed with $100 \mathrm{ng}$ pDR224.

4. Cells are spun down, concentrated and plated on NA/Spec and incubated at $30^{\circ} \mathrm{C}$.

Day 6:

1. Selection cassette removal is checked by colony PCR.

2. Positive clones are plated on NA/Zeo (to check $A B R$ loss) and on LB at $37^{\circ} \mathrm{C}$ to cure pDR244.

Day 7:

1. pDR244 curation is checked by plating cells on LB/Spec.

CRISPR. Adapted from ${ }^{7}$ 
(Note) sgRNA sequence used: 5' - promoter - ATTTAGAGCCCTGCCGTGCA - scaffold - terminator 3'. sgRNA sequence obtained using ${ }^{4}$.

Day 1:

1. Start an overnight culture $37^{\circ} \mathrm{C}$ in minimal medium (MM: $10 \mathrm{ml} S M M$ basic salts, $125 \mu \mathrm{l} 40 \%(\mathrm{w} / \mathrm{v})$ glucose, $100 \mu \mathrm{l} 2 \%(\mathrm{w} / \mathrm{v})$ tryptophan, $60 \mu \mathrm{l} 1 \mathrm{M} \mathrm{Mg} 2 \mathrm{SO} 4 * 7 \mathrm{H} 2 \mathrm{O}, 10 \mu \mathrm{l}$ $20 \%(\mathrm{w} / \mathrm{v})$ casamino acids, $5 \mu \mathrm{l} 2.2 \mathrm{mg} / \mathrm{ml}$ ferric ammonium citrate).

Day 2:

1. Dilute cells $1: 10$ in $M M$ and grown for $3 \mathrm{~h}$ at $37^{\circ} \mathrm{C}$. Meanwhile, starvation medium (SM: $10 \mathrm{ml} \mathrm{SMM} \mathrm{basic} \mathrm{salts,} 125 \mu \mathrm{l} 40 \%$ (w/v) glucose, $60 \mu \mathrm{l} 1 \mathrm{M} \mathrm{Mg} 2 \mathrm{SO} 4^{\star} 7 \mathrm{H} 2 \mathrm{O}$ ) is prepared and prewarmed at $37^{\circ} \mathrm{C}$.

2. Dilute in $1: 2 \mathrm{SM}$ and make competent cells with a further $2 \mathrm{~h}$ incubation period at $37^{\circ} \mathrm{C}$.

3. Mix $400 \mu \mathrm{l}$ cell with $400 \mathrm{ng}$ pBS-CRISPR-BC. Spin down cells and plate on LB/Kan/Mannose $0.2 \%$ and incubate at $30^{\circ} \mathrm{C}$ for $1 \mathrm{~h}$.

Day 3:

4. Barcode presence is checked by colony-PCR.

5. Cure positive clones from pJOE-BC by restreaking them at $37 \mathrm{C}$ in LB plates

Day 4:

6. Store kanamycin sensitive clones as barcoded. 


\section{Supplementary Figures}

A
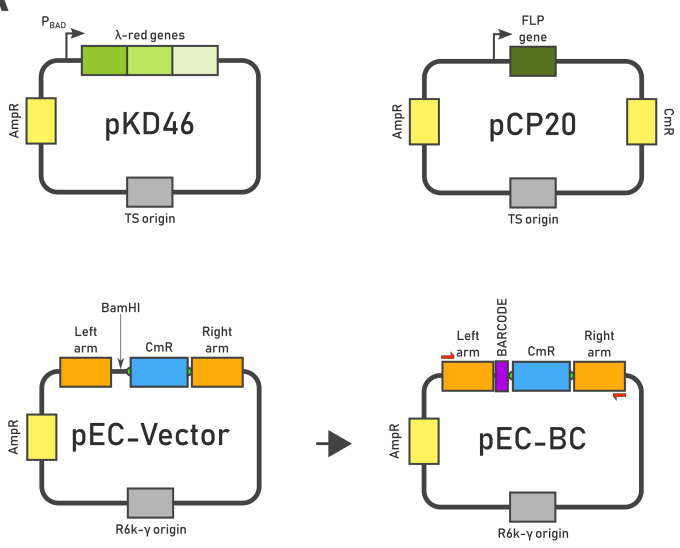

C
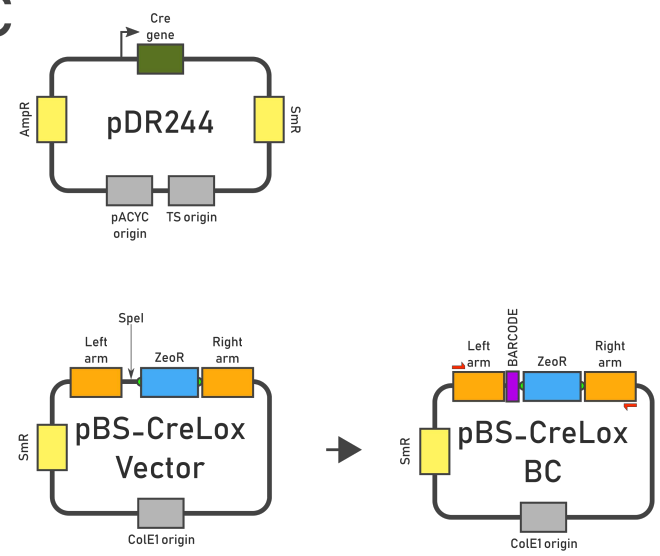

B
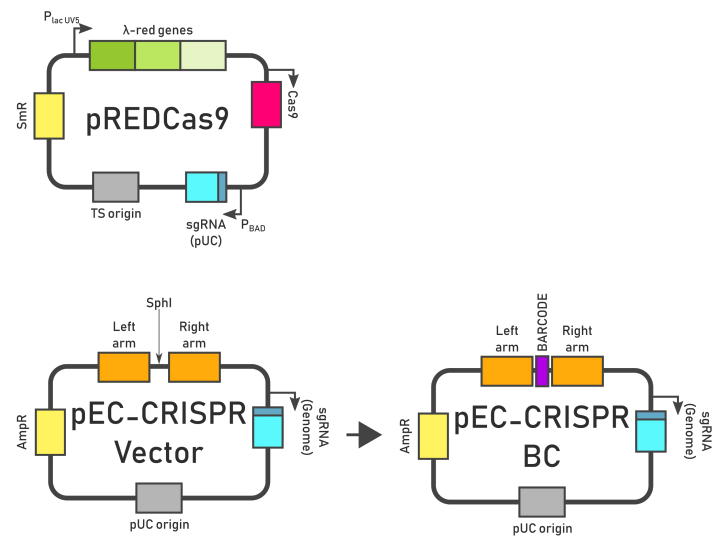

D

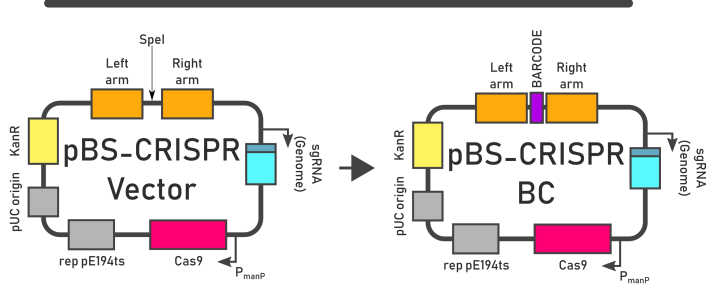

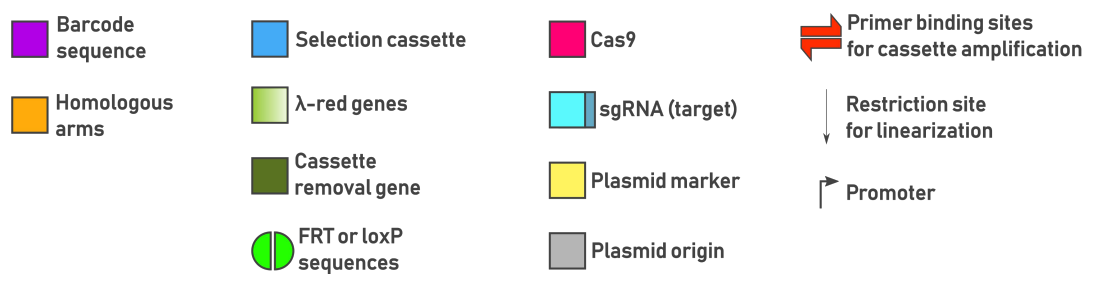

Figure S3. Maps of the plasmids used for barcoding purposes. A) E. coli $\lambda$-Red mediated barcoding plasmids. B) E. coli CRISPR barcoding. C) B. subtilis Cre-Lox barcoding plasmids. D) B. subtilis CRISPR barcoding plasmids. 


\section{BARCODE STABILITY ASSAYS}

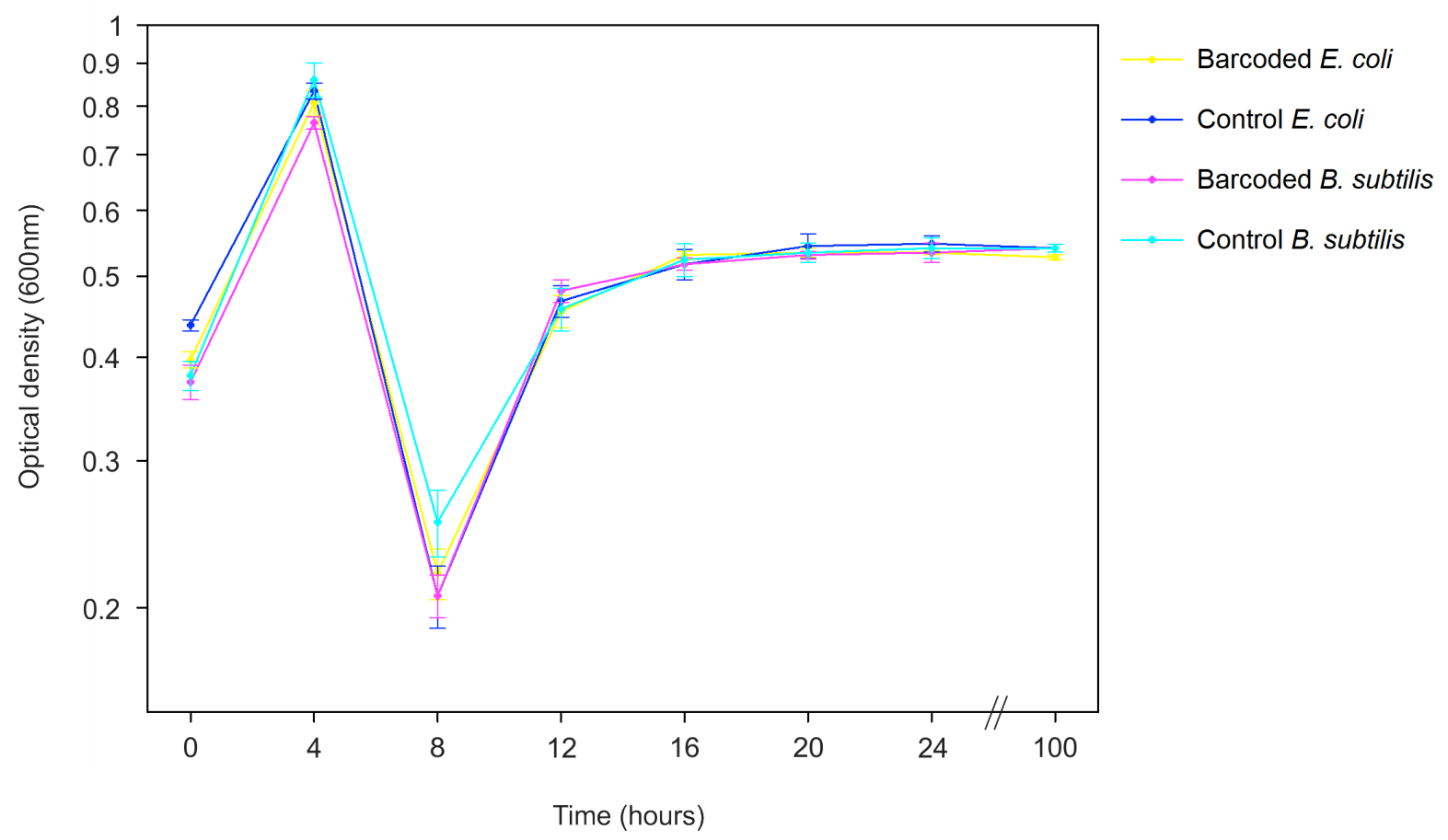

Figure S4. Optical density (OD600) measurements initially vary in continuous flow bacterial cultures. Cultures adjust their growth to nutrients limitation and rapidly reach steady state, where same optical densities can be observed up to a hundred hours (or more). OD measurements are shown for 4 individual experiments (barcoded and control E. coli, barcoded and control B. subtilis), each performed in triplicate. Error bars show the standard error of the mean across samples. 
Initial E. coli

subculture experiment

96-well plate
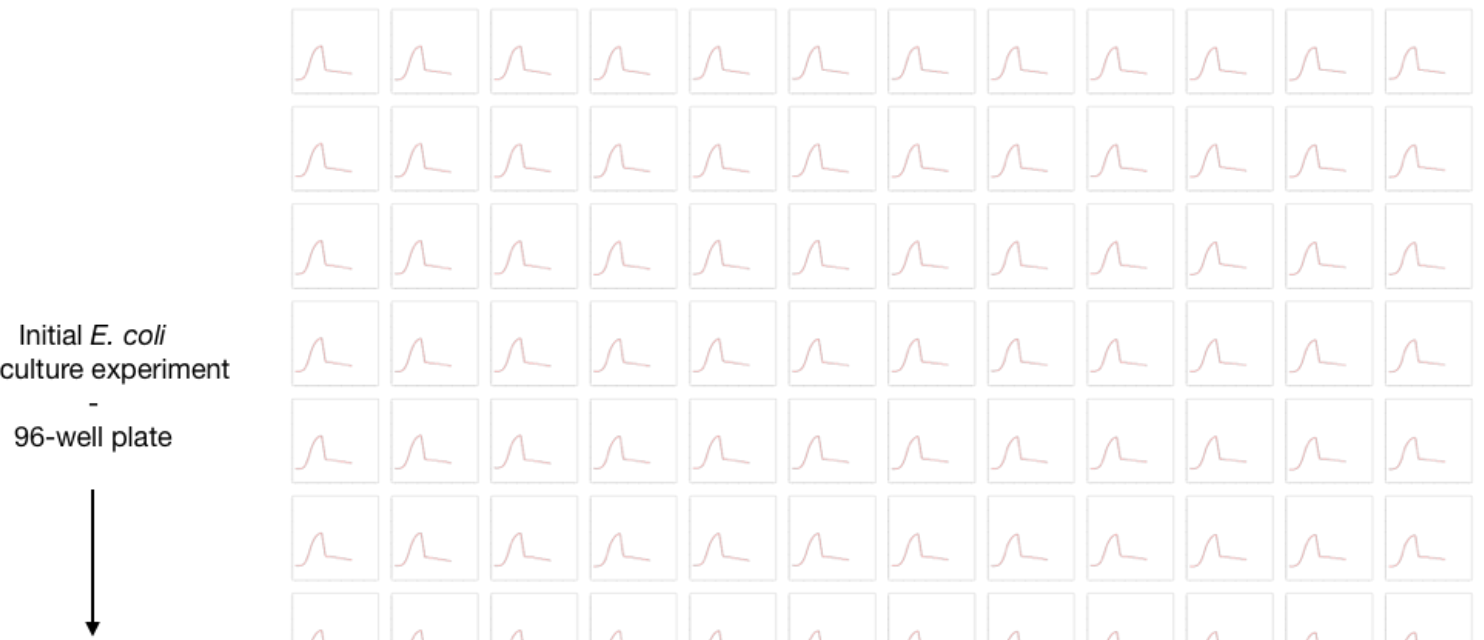

Harvest cells

at early (6h)

and late (12h)

time points

sCPW03 average growth curve (early subculture 9)

Subculture cells $10 x$ and sequence barcodes
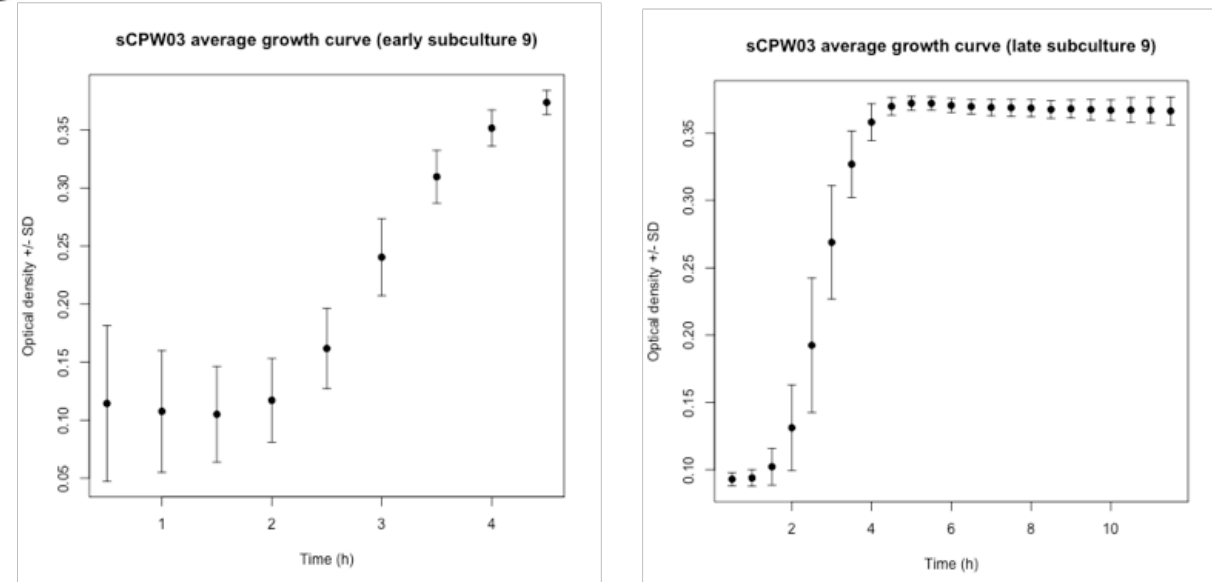

Figure S5. Overview of the high-throughput experiments for E. coli. Top panel shows growth of the initial 96-well plate that was used throughout this assay, sampled after a $6 \mathrm{~h}$ incubation period or a prolonged $12 \mathrm{~h}$ period where cells are left in stationary phase. Nine subsequent cultures - following early/late samples separately - were carried out before extracting DNA for sequencing. In the bottom panel, growth curves are averaged for the 96 samples of the same plate after the ninth subculture experiment, and error bars show standard deviation. 
nitial $B$. subtilis subculture experiment

96-well plate

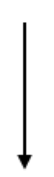

Harvest cells

at early (6h)

and late (12h)

time points

sCPW04 average growth curve (early subculture 9)

Subculture cells $10 x$ and sequence barcodes
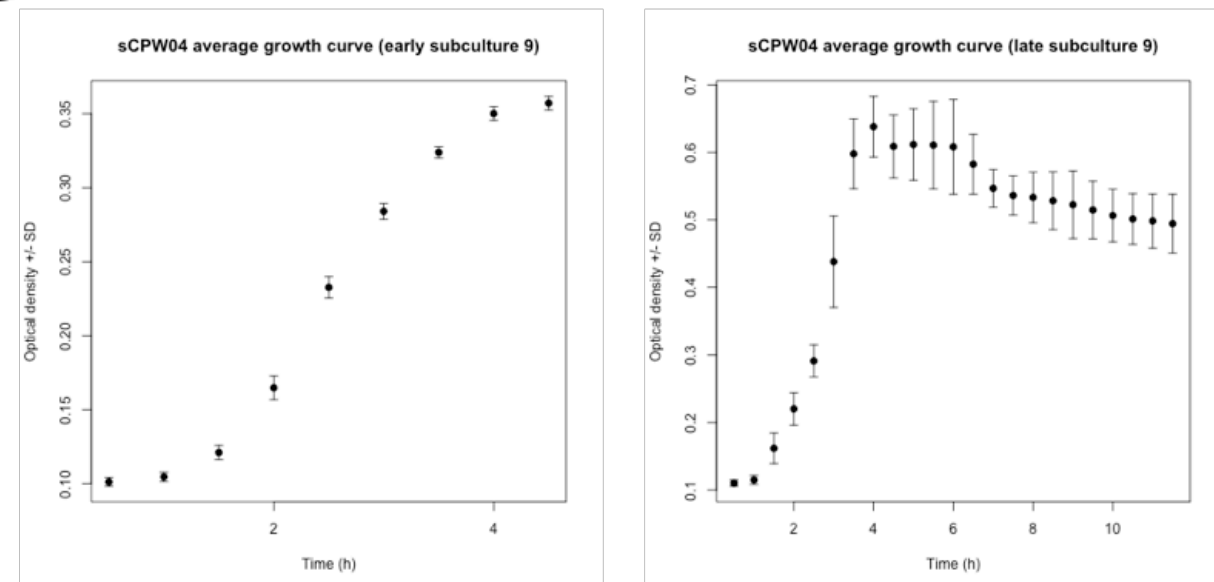

Figure S6. Overview of the high-throughput experiments for $B$. subtilis. Top panel shows growth of the initial 96-well plate that was used throughout this assay, sampled after a $6 \mathrm{~h}$ incubation period or a prolonged $12 \mathrm{~h}$ period where cells are left in stationary phase. Nine subsequent cultures - following early/late samples separately - were carried out before extracting DNA for sequencing. In the bottom panel, growth curves are averaged for the 96 samples of the same plate after the ninth subculture experiment, and error bars show standard deviation. 


\section{Supplementary Tables}

Table S1. Efficiency of the described barcoding methods. All the experiments were carried out in three different replicas testing 8 colonies by PCR each time. After transformation with the PCR product/plasmid, 8 colonies per replica were boiled and used as template PCR. The table shows how many positive clones were obtained in all experiments.

\begin{tabular}{|c|c|c|c|c|}
\hline Species & Method & $\begin{array}{c}\text { Positive clones } \\
\text { Replica 1 }\end{array}$ & $\begin{array}{c}\text { Positive clones } \\
\text { Replica 2 }\end{array}$ & $\begin{array}{c}\text { Positive clones } \\
\text { Replica 3 }\end{array}$ \\
\hline \multirow{2}{*}{ E. coli } & $\lambda$-Red & 7 & 7 & 8 \\
\cline { 2 - 5 } & CRISPR & 8 & 8 & 8 \\
\hline \multirow{2}{*}{ B. } & Toxin/Antitoxin & 8 & 7 & 8 \\
\cline { 2 - 5 } subtilis & Cre-Lox & 6 & 7 & 7 \\
\cline { 2 - 5 } & CRISPR & 7 & 8 & 7 \\
\hline
\end{tabular}

Table S2. Calculation of expected mutations using referenced mutation rates specific for each organism. The calculation was made for a $123 \mathrm{bp}$ barcode sequence after 200 generations.

\begin{tabular}{|c|c|c|c|}
\hline Species & Reference & $\begin{array}{c}\text { Mutation rate } \\
\text { (per bp per generation) }\end{array}$ & $\begin{array}{c}\text { Expected mutations in the } \\
\text { barcode sequence }\end{array}$ \\
\hline E. coli & 8 & $2.2 \times 10^{-10}$ & $5.41 \times 10^{-6}$ \\
\hline B. subtilis & 9 & $3.28 \times 10^{-10}$ & $8.07 \times 10^{-6}$ \\
\hline
\end{tabular}

\section{REFERENCES}

(1) Casini, A.; Christodoulou, G.; Freemont, P. S.; Baldwin, G. S.; Ellis, T.; MacDonald, J. T. R2oDNA Designer: Computational Design of Biologically Neutral Synthetic DNA Sequences. ACS Synth. Biol. 2014, 3 (8), 525-528. https://doi.org/10.1021/sb4001323.

(2) Datsenko, K. A.; Wanner, B. L.; Beckwith, J. One-Step Inactivation of Chromosomal Genes in Escherichia Coli K-12 Using PCR Products. Proc. Natl. Acad. Sci. U. S. A. 2000, 97 (12), 6640-6645.

(3) Li, Y.; Lin, Z.; Huang, C.; Zhang, Y.; Wang, Z.; Tang, Y.; Chen, T.; Zhao, X. Metabolic Engineering of Escherichia Coli Using CRISPR-Cas9 Meditated Genome Editing. Metab. Eng. 2015, 31, 13-21. https://doi.org/10.1016/J.YMBEN.2015.06.006.

(4) Labun, K.; Montague, T. G.; Krause, M.; Torres Cleuren, Y. N.; Tjeldnes, H.; Valen, E. CHOPCHOP v3: Expanding the CRISPR Web Toolbox beyond Genome Editing. Nucleic Acids Res. 2019, 47 (W1), W171-W174. https://doi.org/10.1093/nar/gkz365.

(5) Lin, Z.; Deng, B.; Jiao, Z.; Wu, B.; Xu, X.; Yu, D.; Li, W. A Versatile Mini-MazFCassette for Marker-Free Targeted Genetic Modification in Bacillus Subtilis. J. 
Microbiol. Methods 2013, 95, 207-214. https://doi.org/10.1016/j.mimet.2013.07.020.

(6) Koo, B. M.; Kritikos, G.; Farelli, J. D.; Todor, H.; Tong, K.; Kimsey, H.; Wapinski, I.; Galardini, M.; Cabal, A.; Peters, J. M.; et al. Construction and Analysis of Two Genome-Scale Deletion Libraries for Bacillus Subtilis. Cell Syst. 2017, 22, 291-305. https://doi.org/10.1016/j.cels.2016.12.013.

(7) Altenbuchner, J. Editing of the Bacillus Subtilis Genome by the CRISPR-Cas9 System. Appl. Environ. Microbiol. 2016, 82 (17), 5421-5427. https://doi.org/10.1128/AEM.01453-16.

(8) Lee, H.; Popodi, E.; Tang, H.; Foster, P. L. Rate and Molecular Spectrum of Spontaneous Mutations in the Bacterium Escherichia Coli as Determined by WholeGenome Sequencing. Proc. Natl. Acad. Sci. U. S. A. 2012, 109 (41), E2774-E2783. https://doi.org/10.1073/pnas.1210309109.

(9) Sung, W.; Ackerman, M. S.; Gout, J.-F.; Miller, S. F.; Williams, E.; Foster, P. L.; Lynch, M. Asymmetric Context-Dependent Mutation Patterns Revealed through MutationAccumulation Experiments. Mol. Biol. Evol. 2015, 32 (7), 1672-1683. https://doi.org/10.1093/molbev/msv055. 